\title{
THE DUTY TO SUPPORT THE INDIGENT ELDERLY IN SOUTH AFRICA: \\ A PUBLIC OR PRIVATE DUTY?
}

\author{
Marita Carnelley \\ BA LLB LLM PhD \\ Professor of Law, College Dean of Research \\ University of KwaZulu-Natal
}

Mothokoa Mamashela

LLB LLM LLM

Honorary Research Fellow

University of KwaZulu-Natal

SUMMARY

Only about $5 \%$ of South Africa's elderly save enough to retire adequately. The legal system makes provision for a dual support system for the indigent elderly: the common law places the burden of support on their financially able children and the State has a constitutional obligation, as it recognises social assistance as a basic human right within a financially constrained paradigm. The boundaries of each system and the interaction between them are, however, not always clear. The question of who is best placed to take responsibility for the indigent elderly has led to a prolific debate in other jurisdictions. The arguments raised in favour of assigning the care of the elderly to financially able adult children are mostly based on their relationship and the tax burden that will be placed on Government should the burden be exclusively shifted to the State. Arguments against filial duty are based on the loosening of family bonds and reasons of public policy. This article discussed both the South African private and public support systems, and concludes that the shared responsibility should remain. It is recommended that the State should, however, further empower children to support their parents through a variety of programmes and strategies.

"The retirement landscape in South Africa is not a positive one ... South Africans often leave retirement on the backburner in favour of immediate gratification."

Olivier "The Great Savings Debate: Retirement vs Education" 28 October 2015 Fin24 http://www.fin24.com/Finweek/Personal-finance/The-great-savings-debate-Retirement-vseducation-20151028 (accessed 2016-01-16). 


\section{$1 \quad$ INTRODUCTION}

With the publication of the Taxation Laws Amendment $\mathrm{Act}^{2}$ in January $2016,{ }^{3}$ the financial status of the elderly was again highlighted by the public controversy the Act caused. ${ }^{4}$ The aim of the legislature was to "harmonise the tax treatment of contributions across all retirement funds": ${ }^{5}$ placing a limit on the lump-sum single payment at retirement and providing that two-thirds of the value of retirement value be paid into an annuity. ${ }^{6}$ These forced preservation measures by the State should be seen in light of statistics that suggest that only about $5 \%$ of South Africans save enough to retire adequately $^{7}$ - often having used their retirement benefits during their working life for the settling of debt. $^{8}$ Consequently, many of the elderly cannot support themselves later in life and thus become dependent on their families and/or the State.

There have also been numerous other developments during the past century that have impacted on the elderly, and which may necessitate a reassessment of the current policy and/or legal principles. These developments include the adoption of the Older Persons Act, ${ }^{9}$ to promote respect, dignity and the best interests of the elderly, as well as a conciliatory approach to problem-solving; and continued general levels of poverty resulting in many people being unable to "save adequately for retirement because of low earnings during their working life". ${ }^{10}$ In South Africa, about three-quarters of the elderly receive grants. ${ }^{11}$ Furthermore, the increase in

25 of 2015.

GN 12 in GG 39588 of 2016-01-08.

Smith “New Tax Laws Will 'Poison' Zuma's Relationship with Workers - Cosatu” 13 January 2016 Fin 24 http://www.fin24.com/Economy/Labour/News/new-tax-laws-will-poison-zumasrelationship-with-workers-cosatu-20160113 (accessed 2016-01-16).

5 Explanatory Memorandum on the Taxation Laws Amendment Bill, 2015 (Draft) (22 July 2015) 4.

See s 3(1)(n), (p), (t), (v), (z) and (zC) of the Taxation Laws Amendment Act 25 of 2015. Smith quoting Brenthurst Wealth MD Brian Butchard. See fn 4 above.

Sanlam Benchmark Survey 2015. Pensioners Databook (2015) 11. According to this research, $56.5 \%$ of the respondents who withdrew amounts from their retirement fund before retirement used it to reduce their debt. It was also noted by Minister of Finance Nhlanhla Nene in his 2015 Budget Speech (2015-02-25) 20, that some civil servants are driven to resign from the Government Employees Pension Fund due to "high levels of indebtedness".

913 of 2006 . The objects of the statute include to "maintain and promote the status, wellbeing, safety and security of older persons" (s 2(a)). The general principles include that in "all proceedings, actions or decisions in a matter concerning an older person must (a) respect, protect, promote and fulfil the older person's rights, the best interests of the older person and the rights and principles set out in this Act, subject to any lawful limitation; (b) respect the older person's inherent dignity; (c) treat the older person fairly and equitably; and (d) protect the older person from unfair discrimination on any ground, including on the grounds of the health status or disability of the older person (s 5(2))". The approach with all these matters is one "conducive to conciliation and problem-solving ... and [that] a confrontational approach should be avoided" (s 5(3)(a)). Legal action should be avoided or delayed as far as it could be possible (s $5(3)(b))$. The statute also makes provision for older persons in need of care and protection (s 25), and notification of the abuse of elders (s 26).

10 National Planning Commission National Development Plan. Vision for 2030 (2011) 329, hereinafter referred to as the "NDP".

11 NDP 330-331. 
life expectancy in general due to advances in medical technologies, and combined with rising medical costs, increases the potential long-term support burden. ${ }^{12}$ Moreover, there is a reduction in the number of children per family in certain sectors - combined with changing attitudes towards the elderly as a result of the loosening of family ties in South Africa which have evolved inter alia as a result of the apartheid policy of migrant labour. ${ }^{13}$ The structural disintegration of the South African family is well documented. ${ }^{14}$ The 2013 Statistics South Africa Report comments that the traditional assumption that extended families and the community will take care of the indigent elderly is not necessarily the case anymore, as "many families are simply too disjointed to look after the well-being of older persons. In fact, older persons are increasingly required to play an active care and support role in their respective households." 15

The question raised herein, is whether the law relating to the support of the indigent elderly from a policy perspective is still relevant in South Africa in light of these developments. It may be time to reassess the reality of who is best placed to care for the indigent elderly - the financially able children or the State. Or should the burden remain where it is - shared between the filial relations and the State?

The requirement to care for the elderly is internationally recognised. ${ }^{16}$ This question of who is best placed to take responsibility for the indigent elderly has led to prolific research and debate in America. The arguments raised in favour of assigning the care of the elderly to financially able adult children are mostly based on their relationship and the tax burden that will be placed on Government, should the burden be exclusively shifted to the State. Arguments against filial duty are based on the loosening of family bonds and reasons of public policy. ${ }^{17}$

In contrast, there is little research and debate in South Africa on this point. It is unclear what the reason for this lack of attentiveness is - and one of the aims of this article is to start a legal debate on the issue in the South African context.

12 Burman and Berger "When Family Support Fails: The Problems of Maintenance Payments in Apartheid South Africa: Part II" 19884 SAJHR 334350.

13 Ibid.

14 Green Paper on Families. Promoting family life and strengthening families in South Africa (2012) 3.

15 The percentage of households headed by older persons increased to $19,7 \%$ in 2012 (Statistics South Africa Social Profile of Vulnerable Groups 2002-2012. Report No. 03-19OO (2013) 95). In Nzame v Minister of Safety and Security 2008 JDR 1293 (D) and Mbonambi v Road Accident Fund 2010 JDR 1307 (KZD) - eg, the grandmothers were saddled with the duty of raising and maintaining their grandchildren from their pension grants. In Nzame $v$ Minister of Safety and Security supra par 10, the mother of the three children had absconded and left them with their grandmother, and in Mbonambi $v$ Road Accident Fund supra par 3, the mother of the two children was an unemployed casual worker who was also maintained by her mother. The Green Paper confirms the role that the elderly play in meeting the needs of the family.

16 This is in line with the United Nations Declaration on the Rights of the Elderly (Resolution 46/91) 1991, which reiterated the United Nations Principles for Older Persons: "to add life to the years that have been added to life" and that inter alia "Older persons should have access to adequate food, water, shelter, clothing and health care through the provision of income, family and community support and self-help" (s 1).

17 See discussion in paragraph 5 of this article. 
Although the American arguments mentioned above are also valid here, the South African elderly face additional problems - adding a further dimension to the discussion. HIVIAIDS and its impact on economically active family members increases the burden on the elderly - either as the economically active children have passed away and there are no offspring to approach for support, and/or the elderly are themselves required to assist younger family members. ${ }^{18}$ There is also evidence that speaks to the inadequacy of the elderly grant and the financial and emotional abuse experienced by some of the elderly at the hands of their children, neighbours and even institutions - to access their grants. ${ }^{19}$

At this stage it is expedient to note that South Africa has a dual support system for the indigent elderly - both private and/or public in nature depending on the individual's circumstances. On the one hand, in terms of common law, the burden of support of indigent parents falls on their financially able children. ${ }^{20}$ On the other hand, the State also has a duty to support the indigent elderly where necessary, as the Constitution recognises social assistance as a basic human right. ${ }^{21}$ This State support is in the form of a "non-contributory and income-tested benefit provided by the State ... [b]enefits [that] are financed by general tax revenues", ${ }^{22}$ but this duty should be seen against the constrained fiscal position of the State. ${ }^{23}$

The boundaries of each system and the interaction between them are, however, not always explicit. Should the resources of the children first be exhausted before the burden falls onto the State? Or, is it the other way around - that the resources of the State first be accessed, before the burden falls onto filial relations? Or, can the indigent elderly source support derive from both private and public funds simultaneously?

Each of the two systems will be discussed in detail hereunder and their interaction noted. The article concludes by assessing whether the law and policy should change in light of the arguments raised in the American literature - in as far as these are also applicable here. The following section sets the stage for the discussion - by profiling the elderly in South Africa.

18 The old-age grants make a significant contribution to the income of many households and access to basic services, and often are the only source of income, and pensioners are pressurised to share their grants with unemployed family and children (Stats SA Report 93).

19 SAHRC "SAHRC condemns older persons abuse in South Africa" (10 April 2013) Media Statement; and Ferreira and Lindgren "Elder Abuse and Neglect in South Africa: A Case of Marginalization, Disrespect, Exploitation and Violence" 2008 20(2) Journal of Elder Abuse Negligence 91-107. Some legal remedies to address these problems include protection orders and/or criminal prosecutions in terms of the Domestic Violence Act 116 of 1998, the Older Persons Act 13 of 2006, and the Protection from Harassment Act 17 of 2011. A full discussion hereof falls outside the scope of this article.

20 See discussion in paragraph 3 of this article.

21 S 27(1)(c) determines that all South Africans have the right to appropriate social assistance if they cannot support themselves and their dependants.

22 NDP 329. 
members, and second, the obligation of the State to support the same group.

\section{COMMON-LAW DUTY ON CHILDREN TO SUPPORT THEIR INDIGENT PARENTS}

"We all cringe at the thought of a well-to-do middle-aged couple enjoying travel and leisure while their parents languish in poverty."

\section{Introduction}

According to the South African common law, children owe their indigent parents a duty of support. ${ }^{32}$ This is "one of those areas in which the law gives expression to the moral views of society". ${ }^{33}$ Whether the rationale for the duty is "a sense of dutifulness", ${ }^{34}$ or merely "the obligation is a filial duty" $^{\prime 35}$ - it is settled law. ${ }^{36}$ Apart from the existence of the legal relationship, two additional requirements must be met for a claim to succeed: the parent must be indigent, ${ }^{37}$ and the child must have the financial means to support the parent. ${ }^{38}$

\section{The plaintiff}

In most cases the indigent parent brings the claim personally, ${ }^{39}$ although there are a few cases reported where the parent litigates against the child directly - most judgments deal with insurance claims, based on the road

31 Britton "America's Best Kept Secret: An Adult Child's Duty to Support" 1989-1990 26 California Western LR 351-372 and 353.

32 Voet 25.3.8; Van Leeuwen Cens For 1.10.4; Spiro The Law of Parent and Child (1985) 403; Van Heerden, Cockrell and Keightly Boberg's Law of Persons and the Family (1999) 248; In re Knoop 1892-1893 10 SC 198; Wright v Wright 1907 TH 204; Vos v Vos 1927 WLD 285; and Khan $v$ Padayachy 1971 (3) SA 877 (W) 879. The same duty is found in customary law (Fosi v Road Accident Fund 2008 (3) SA 560 (C); Nzame v Minister of Safety and Security supra par 10; Mbonambi v Road Accident Fund supra; Mawela v Road Accident Fund 2013 JDR 1818 (GNP); and Dube $v$ Road Accident Fund 2013 JDR 2236 (GNP). No maintenance order needs to exist to prove the duty to maintain (Keforilwe $v$ Road Accident Fund (281/13) [2015] ZANWHC 74 (12 November 2015)).

33 Jacobs v Road Accident Fund 2010 (3) SA 263 (SE) par 20.

34 Spiro The Law of Parent and Child 403.

35 Van Heerden et al Boberg's Law of Persons and the Family 248.

36 Van Vuuren v Sam 1972 (2) SA 633 (A) 639; and Oosthuizen v Stanley 1938 AD 322327 328. "The fact that a child is a minor does not absolve him from his duty, if he is able to provide or contribute to the required support" (Oosthuizen v Stanley supra 327-328; and In re Knoop supra 198).

37 United Building Society v Matiwane 1933 EDL 280; Waterson v Mayberry 1934 TPD 210; Smith v Mutual and Federal Insurance Co Ltd 19983 All SA 378 (C); and Singh v Santam Insurance Co 1974 (4) SA 196 (D).

38 Singh $v$ Santam Insurance Co supra 196 - the court found that although the deceased son made contributions to the family upkeep, he lived above his means and was in fact subsidised, to a large extent, by other employed family members.

39 See, inter alia, United Building Society v Matiwane supra 280; Waterson v Mayberry supra 210; Smith v Mutual and Federal Insurance Co Ltd supra 378; Singh v Santam Insurance Co supra 196; Stander v Royal Exchange Assurance Co 1962 (1) SA 454 (SWA); Graaff v Speedy Transport 1944 TPD 236; and Nisele v AA Mutual Ins Ass Ltd 1980 (3) SA 441 (C). 
accident legislation. There is evidence that some parents are reluctant to claim maintenance directly from their children. They do not want to be a burden on their children or place an unequal burden on some children, as all the children may not have the same financial ability to assist, or regard it as undignified or embarrassing, for fear of negatively impacting on familial relationships. ${ }^{40}$

Where the indigent parent is either infirm or mentally challenged, the claim can be brought on his/her behalf by the curator personae or curator ad litem - depending on the circumstances. Although a curator is an official appointment that must be confirmed by either the High Court or the Master of the High Court, ${ }^{41}$ such official appointments are common. ${ }^{42}$

Whether a third party can claim prospective maintenance remains unclear, although in Riches $v$ Riches $^{43}$ the application against the son was brought by the president of the Victoria Memorial Home for the Aged, on behalf of the indigent mother who resided there. ${ }^{44}$

If the duty to support cannot be exercised upfront, a third party ${ }^{45}$ may have recourse against the children to recover the contributions not made. This would be the case, for instance, where the third party fulfilled the maintenance obligations on behalf of a child vis-à-vis an indigent parent, when the child could and should have done so. The basis for the claim could be either in terms of the principle of negotiorum gestio, managing another's affairs, or unjustified enrichment. ${ }^{46}$ The essence of negotiorum gestio is to compensate the third person who manages the affairs of another (the

40 In Singh v Santam Insurance Co supra 196, the deceased was subsidised by his siblings; in Khan $v$ Padayachy supra 877, the deceased maintained his parents, as the other siblings were unable to; and in Vos $v$ Vos supra 285, the applicant had three sons, but chose to sue only one.

In India, the Maintenance and Welfare of Parents and Senior Citizens Act, 2007 introduced tribunals to assist indigent parents to sue their children for maintenance. However, research showed that only half would consider doing that (Kausar "Half of Delhi's Elderly Would 'Sue Their Children' if they Faced Abuse at their Hands, Survey Finds" 24 January 2014 Mail Online India http://www.dailymail.co.uk/indiahome/indianews/article-2545627/Half-Delhiselderly-sue-children-faced-abuse-hands-survey-finds.html\#ixzz3xm8xxAGS) (accessed 2016-01-20). A similar situation exists in Singapore (Woon "Honour Thy Father and Thy Mother" 199428 June Wall Street Journal A18). Here the Maintenance of Parents Act (Cap 167B) as read with the Maintenance of Parents Rules Notification 1, S241/1996, make provision for a tribunal to deal with these issues - preferably through mediation. See, also, Liu and Kendig Who Should Care for the Elderly? An East-West Value Divide (2000) 253.

41 Heaton Family Law of South Africa 3ed (2010) 336.

42 Letzler "Appointing a Curator ad litem - Are we Applying the Law Correctly?" June 2014 De Rebus 30.

$43 \quad 1910$ EDL 247.

44 The details of the appointment and the legal basis of the finding, is, however, unclear from the judgment.

45 An example of such a third party would be an old-age home where the indigent parent lives.

46 Similar to a claim based on maintenance obligations fulfilled on behalf of the parent vis-à-vis the child, as noted in Van Zyl Die Saalwaarnemingsaksie as Verrykingsaksie in die SuidAfrikaanse Reg. 'n Regshistorise en Regsvergelykende Ondersoek (1970 LLD thesis) 7; Van Heerden et al Boberg's Law of Persons and the Family $243 \mathrm{fn}$ 52; Spiro The Law of Parent and Child 394; and Pretorius v Van Zyl 1927 OPD 226. Also discussions by De Vos Verrykingsaanspreeklikheid 3ed (1987) 299; and Du Plessis The South African Law of Unjustified Enrichment (2012) 327-328. 
financially able child) - without being expressly authorised to do $\mathrm{so}^{47}$ in a useful and reasonable way. ${ }^{48}$ And, although there is currently no general enrichment action in South African law, the claim could be possible if the elements of an unjustified enrichment action are met: ${ }^{49}$ one, the defendant must be enriched (in casu the financially abled child who saved on expenses); two, the plaintiff (third party) must be impoverished (spending funds where there is no legal duty to do so); three, the defendant's enrichment must be at the expense of the plaintiff, and four, that there is no legal ground or justification for the retention of the enrichment. Du Plessis argues that the action is based on the unauthorised fulfilment of another's obligation $^{50}$ in the form of saving the relative (in our discussion the financially able child) maintenance costs. ${ }^{51}$ This claim will, however, not succeed if the third party maintained the elderly out of affection - and with the intention to make a donation. ${ }^{52}$

\section{Indigence and scope of maintenance}

For the claim to be supported to succeed, either fully or partially, the parent must be indigent, and this is a question of fact - depending on the circumstances of each case. ${ }^{53}$ Failure to allege indigence and the inability to support oneself in the pleadings would be fatal to the claim. ${ }^{54}$ Proof of indigence must be provided on a balance of probabilities. ${ }^{55}$ The Courts' interpretation of the word "indigent" has, however, not been uniform. Some courts have interpreted it more narrowly than others. According to Smith, the parent "must be in extreme need of what should, considering his or her station in life, be regarded as the necessities of life". ${ }^{56}$ However, in Nzame $v$ Minister of Safety and Security, ${ }^{57}$ the Court disagreed with this stringent test and viewed the common-law duty of support as a flexible concept - to be

47 Van Zyl Mandate and Negotiorum Gestio LAWSA XVII $20092^{\text {nd }}$ par 22 - where the child is aware that the third party is supporting the indigent parent (tacit or implied consent) and explicitly consents to it, it is no longer negotiorum gestio, but a mandate (LAWSA XVII par 22).

48 LAWSA XVII par 24.

49 McCarthy Retail Ltd v Short Distance Carriers CC 2001 (3) SA 482 (SCA) par [15]-[25]; Visser Unjustified Enrichment (2008) 47-48; and Du Plessis The South African Law of Unjustified Enrichment 24.

50 Du Plessis The South African Law of Unjustified Enrichment 309.

51 Du Plessis The South African Law of Unjustified Enrichment 327. Although Du Plessis refers to spousal maintenance with reference to Gammon v McClure 1925 CPD 137 139, he argues that the same principle is applicable to child maintenance (Du Plessis The South African Law of Unjustified Enrichment 328). There is no reason why the same principle should not apply to parental maintenance.

52 Du Plessis The South African Law of Unjustified Enrichment 328. See, also, Barnes v Union and South West Africa Insurance Co Ltd 1977 (3) SA 502 (E).

53 Oosthuizen v Stanley supra 327-328; JT v Road Accident Fund 2015 (1) SA 609 (GJ) par 26; and Tutubala v Road Accident Fund (2014/34463) [2015] ZAGPJHC 149 (23 July 2015) par 15.

54 Gajoo v Road Accident Fund (13128/2013) [2015] ZAGPPHC 927 (17 November 2015) par 19; Waterson v Mayberry supra 211; and United Building Society v Matiwane supra 285.

55 Smith v Mutual and Federal Insurance Co Ltd supra 379.

56 Ibid; Heaton Family Law of South Africa 329; and Waterson v Mayberry supra 210. This stringent criterion of "extreme need" was applied in Singh v Santam Insurance Co supra.

57 Supra. 
developed and extended by the courts. Further, the Court regarded the test of "extreme need" as being out of line with the rights to adequate shelter, nutrition and healthcare, which are enshrined in the Constitution. ${ }^{58}$ The Court argued that sections 26 and 27 of the Constitution supported the view that while the parent's position in life is clearly a relevant factor, the prevailing mores of society demand that there is a certain minimum standard below which human beings should not be allowed to live. ${ }^{59}$ In the view of the Court, persons who fell short of such minimum standards are entitled to claim support - provided the remaining requirements are satisfied. ${ }^{60}$ The Court in Jacobs $v$ Road Accident Fund noted that "the deciding principle ... is whether the parent can prove that he or she was dependant on the child's contribution for the necessities of life. What constitutes necessities will in turn depend on the parent's station". ${ }^{61}$

The ownership of substantial capital assets would disentitle a parent from claiming maintenance from a child - as it would disprove indigence. ${ }^{62}$

The scope of the maintenance claim by an indigent parent against a child is determined in principle, more austerely than a claim by a child against a parent. ${ }^{63}$ It will include, depending on the standard of living of the parties accommodation, food, daily necessaries and medical needs. ${ }^{64}$ However, legal fees for a criminal matter may not be regarded as a necessity. ${ }^{65}$ In addition, support "in kind" could be ordered, such as that the parent must rather live with the child to save expenses. ${ }^{66}$ In Wigham, the Court stated that:

"I think the authorities furthermore make it clear that in order to succeed a plaintiff is not required to show that she would be reduced to abject poverty or starvation and be a fit candidate for admission to a poor house unless she received the contribution. The Court must have regard to her status in life, to what she has been used to in the past and the comforts, conveniences and

Nzame v Minister of Safety and Security supra par 4.

Ibid.

60 Nzame $v$ Minister of Safety and Security supra par 4-5.

Jacobs $v$ Road Accident Fund supra par 20

62 Volkenborn v Volkenborn 1946 NPD 7678.

63 Van Zyl Handbook of the SA Law of Maintenance 2ed (2005) 22; Van Vuuren v Sam supra 642; Oosthuizen v Stanley supra 328; and Caldwell v Erasmus 1952 (4) SA 43 (T) 50.

64 Support does not only include "food and clothing in accordance with the quality and condition of the persons to be supported, but also lodging and care in sickness; see Voet 25.3.4, Van Leeuwen Cens For 1.10 .5 (Oosthuizen v Stanley supra 327-328). In Grove v Baillie 1942 WLD 34, the Court noted that maintenance included more than accommodation. See, also, Smith v Mutual and Federal Insurance Co Ltd supra 384. In Mann v Leach [1998] 2 All SA 217 (E) 221-222, in a claim in terms of the Maintenance of Surviving Spouses Act 27 of 1990, the claim included a new motor vehicle and ongoing medical expenses. The Court made an order compelling the elderly parent-plaintiff to undergo medical examinations to confirm her general state of health, eyesight and capacity to drive - as she refused to voluntarily submit herself to such examinations.

65 In Caldwell $v$ Erasmus supra 43, the applicant father stabbed his son to death. As the deceased son had some money in the Guardian's Fund, the applicant requested the Master of the High Court to pay his legal fees and bail from the Fund. The request was denied as legal fees for his defence were not a necessity.

66 In Groves v Baille supra 34, the argument of "in kind" accommodation was raised, but no order was made as the son could afford to support his parent financially. In this judgment, only one of four children was sued for contributions towards the indigent mother. Their incomes and contributions were not taken into account. 
advantages to which she has been accustomed ... The aim and object is to place the dependants in as good a position as regards maintenance as they would have been if the deceased had not been killed, to which end material losses as well as benefits and other prospects must be considered."

\section{Defendant}

The claim can be made against the child directly or from third parties - most commonly the third-party insurer in terms of the motor-vehicle insurance legislation, resulting from the death of the financially able child in a motor vehicle accident. $^{68}$

The duty, however, does not arise if there is a spouse or civil union partner who can support the indigent parent. ${ }^{69}$ The duty rests in the first place with the other spouse,${ }^{70}$ and only if that spouse has passed away, or is unable, or fails to support the indigent spouse, would the child assume the duty to support the indigent parent. ${ }^{91}$

"If a parent or grandparent has more than one child or grandchild or a sibling has more than one sibling, the children, grandchildren or siblings must contribute according to their respective means." ${ }^{72}$ Where one child or grandchild supports the indigent elder, a right to recourse would exist against the other family members who should have contributed.

A stepparent is not entitled to claim maintenance from a stepchild, as the basis for the claim is the blood relationship. ${ }^{73}$ The exception is adoptive children that are regarded as children with full legal status. ${ }^{7}$

The maintenance duty can extend to the grandchildren. ${ }^{75}$ However, as long as an indigent grandparent has a spouse, civil union partner or children able to support him, no claim will arise against a grandchild. ${ }^{7}$

67 Wigham v British Traders Insurance Company Ltd 1963 (3) SA151 (W), quoted with approval in Mtetwa v Road Accident Fund (70650/2013) [2015] ZAGPPHC 446 (3 July 2015) par 12.

68 See the various cases discussed hereunder. In these matters, failure by the child to maintain the parent during their lifetime would negate the claim after the death of the child (Singh $v$ Santam Insurance Co supra 196)). Here there was evidence that the deceased son was a spendthrift and was subsidised by other family members - and the Court ordered absolution from the instance (196). See, also, Waterson v Mayberry supra 211 (claim for maintenance from a person that killed his child) and Fosi $v$ Road Accident Fund supra 562 (son's duty towards his mother under customary law). See, also, Nzame v Minister of Safety and Security supra; Dube v Road Accident Fund supra 2236; and Mawela v Road Accident Fund supra 1818.

69 Heaton Family Law of South Africa 329; and Osman v Road Accident Fund (16780/13) [2015] ZAGPPHC 517; 2015 (6) SA 74 (GP) (3 July 2015) par 7.

70 Manuel v African Guarantee and Indemnity Co Ltd 1967 (2) SA 417 (R); and Smit v Smit 1946 WLD 360.

71 Van Vuuren v Sam supra 639; and Oosthuizen v Stanley supra 327-328.

72 Heaton Family Law of South Africa 329.

Jacobs $v$ Cape Town Municipality 1935 CPD 474; and Ford v Allen 1925 TPD 5.

S 242(3) of the Children's Act 38 of 2005.

Heaton Family Law of South Africa 329.

76 Tyali v University of Transkei [2002] 2 All SA 47 (Tk); and Barnes v Union and South West Africa Insurance Co Ltd supra 502. In Barnes, a grandchild maintained her grandmother out of goodwill even though the latter's three children were still alive. The Court reiterated that the legal duty to maintain a grandparent first fell upon his/her children, and the (deceased) 


\section{Procedure}

Procedurally the Maintenance Act 99 of 1998 provides for the process of obtaining maintenance in the maintenance courts, as well as the civil and criminal enforcement mechanisms - although enforcement of orders remains problematic. ${ }^{77}$

\section{Possible defences}

The children have the usual defences against a claim from their indigent parent for maintenance - the most important being their own financial inability. ${ }^{78}$

It is, however, unclear whether the defence of "gross ingratitude", similar to the possible defence of a parent, vis-à-vis maintenance duty for a child, would be available to the child being sued for maintenance by the indigent parent. In addition, it is also unclear if the defence may be raised that there should be no reciprocal maintenance duty now, as the (now indigent) parent had abandoned the child as a child, and did not support that child when that child needed support. This would seem unlikely, although no precedent exists.

\section{Constitutionality}

Another issue to be raised is whether the duty on adult children to support their indigent parents is constitutional. Does it not offend the equality clause $^{79}$ because of the potential difference in the treatment of parents by their children based on their different financial abilities? ${ }^{80}$ Or, do these distinctions fall within the limitation clause, as a limitation that is reasonable and justifiable in an open and democratic society? ${ }^{81}$

As the duty to support a parent is a common-law provision, the Court must, when developing the common law, promote the spirit, purport and objects of the Bill of Rights. ${ }^{82}$ Using the standard Harksen $v$ Lane $\mathrm{NO}^{83}$ test

grandchild was not legally bound to support the grandmother, but did so out of love. Although the plaintiff (grandmother) proved that she was indigent, she failed to prove that the deceased owed her a legal duty of support. Barnes $v$ Union and South West Africa Insurance Co Ltd supra 510.

77 A full discussion hereof falls outside the scope of this article. See, in general, Carnelley "A Review of the Criminal Prosecution and Sentencing of Maintenance Defaulters in South Africa, with Commentary on Sentencing Strategies" 2012 25(3) SAJCJ 343-360.

78 Riches $v$ Riches supra 247.

79 S 9(1)-(3) of the Constitution. Although "financial ability" is not listed as a ground for unfair discrimination, it should be noted that the list is not a numerus clausus.

80 In this regard, the inequality may be exacerbated if one (unemployed) child still lives with the indigent parent, while another financially able child is required to maintain both the parent and the sibling, such as the facts suggest in Leask $v$ Road Accident Fund (33281/2013) [2015] ZAGPJHC 76 (30 April 2015) 4. Legally the duty to support may be extended to siblings (Heaton Family Law of South Africa 329). The issues of the difference in the treatment of parents with children and that of those without, are disregarded for purposes of this article.

$81 \mathrm{~S} 36$ of the Constitution.

$82 \mathrm{~S} 39(2)$ of the Constitution. 
to determine the constitutionality based on equality discrimination, the first question is whether the provision differentiates between people or categories of people. The answer here is affirmative. Secondly, does the differentiation bear a rational connection to a legitimate government purpose? It is argued that the maintenance of indigent parents by financially able children bears a rational connection to a legitimate government purpose - namely to use limited tax resources only for indigent parents who cannot support themselves.

However, should this argument be incorrect, the next question is whether the differentiation between children amounts to unfair discrimination. In this case, the distinction seems prima facie discriminatory, but not on any specified ground listed in the Constitution. However, objectively, the ground ("financial ability") is "based on attributes and characteristics which have the potential to impair the fundamental human dignity of persons as human beings and as it affects them adversely in a comparably serious manner". ${ }^{84}$ As the differentiation is not on any specified ground, unfairness will have to be established by the complainant. ${ }^{85}$ The Court in Harksen $v$ Lane NO noted that the test of unfairness focuses primarily on the impact of the discrimination on the complainant and others in his situation. ${ }^{86}$ In our case the difference may be striking.

Presuming, for the sake of argument, that in the sibling maintenance scenario, the differentiation is regarded as unfair (as it burdens some children, but not others), the next step is to determine whether it can be justified under the limitations clause. It is submitted that it is justified, taking into account the right itself (equality of children of different financial standing) and the importance of the purpose of the limitation (to support indigent parents); the nature and extent of the limitation (only those with financial ability are burdened); and the relation between the limitation and its purpose

831998 (1) SA 300 (CC)) par 53: The equality analysis was summarised as follows:

"(a) Does the provision differentiate between people or categories of people? If so, does the differentiation bear a rational connection to a legitimate government purpose? If it does not then there is a violation of $s$ 8(1). Even if it does bear a rational connection, it might nevertheless amount to discrimination.

(b) Does the differentiation amount to unfair discrimination? This requires a two stage analysis: (i) Firstly, does the differentiation amount to 'discrimination'? If it is on a specified ground, then discrimination will have been established. If it is not on a specified ground, then whether or not there is discrimination will depend upon whether, objectively, the ground is based on attributes and characteristics which have the potential to impair the fundamental human dignity of persons as human beings or to affect them adversely in a comparably serious manner. (ii) If the differentiation amounts to 'discrimination', does it amount to 'unfair discrimination'? If it has been found to have been on a specified ground, then unfairness will be presumed. If on an unspecified ground, unfairness will have to be established by the complainant. The test of unfairness focuses primarily on the impact of the discrimination on the complainant and others in his or her situation. If, at the end of this stage of the enquiry, the differentiation is found not to be unfair, then there will be no violation of $s 8(2)$.

(c) If the discrimination is found to be unfair then a determination will have to be made as to whether the provision can be justified under the limitations clause (s 33 of the interim Constitution)."

84 Harksen $v$ Lane supra par 46.

85 Harksen $v$ Lane supra par 47.

86 Harksen $v$ Lane supra par 50. 
(the duty is only for the basic necessities, and where the parents are indigent). However, is there a less restrictive means to achieve the purpose? It is submitted that there is none - as the Government has limited funds to support the indigent and cannot support all the elderly. As will be seen hereunder, this conclusion is in line with jurisprudence in the USA.

The constitutional issues have been raised in America, where the statutes enforcing these duties have been found to be constitutional: as the aim of the principle is to relieve the State of the burden of caring for the destitute elderly, it serves a legitimate State purpose ${ }^{87}$ The court in Swoap v Superior Court, ${ }^{88}$ found that the principle did not breach the constitutional principle of equal protection. ${ }^{89}$ The classification was found to be rational in that the parents are now in need, and they had supported and cared for their children during their childhood, and "since these children received special benefits from the class of 'parents in need', it is entirely rational that the children bear a special burden with respect to that class". ${ }^{90}$ It is submitted that similar arguments can be raised in South Africa.

As mentioned above, the duty to support is both private and public. The above discussion related to the private sphere. The next section notes how the support of the indigent elderly is dealt with in the public sphere.

\section{DUTY ON THE STATE TO SUPPORT THE INDIGENT ELDERLY}

The Social Assistance Act 13 of 2004 provides for social assistance benefits to a number of beneficiaries - including the elderly. To be eligible for the grant, the elderly person must either be a South African citizen, a permanent resident, or a refugee over 60 years of age, and must live in the country ${ }^{91}$ and meet the financial criteria set out in the Act. ${ }^{92}$ The applicant may not derive benefit from another social grant and may not be maintained in any state-funded institution or otherwise be funded by the State. ${ }^{3}$

87 Walters "Pay Unto Others as They Have Paid Unto You: An Economic Analysis of the Adult Child's Duty to Support an Indigent Parent" 2000-2001 11 Journal of Contemporary Legal Issues 276 376; and Kline "A Rational Role for Filial Responsibility Laws in Modern Society" 1992 26(3) Family Law Quarterly 19209.

8810 Cal.3d 490, 506 (1973).

89 Narayanam "The Government's Role in Fostering the Relationship between Adult Children and their Elder Parents" 19964 Elder Law Journal 369 380; Lundberg "Our Parents' Keepers: The Current Status of American Filial Responsibility Laws" 200911 Journal of Law and Family Studies 533 537; and Ross "Taking Care of Our Caretakers: Using Filial Responsibility Laws to Support the Elderly Beyond the Government's Assistance" 200816 The Elder Law Journal 167194.

90 Swoap v Superior Court supra 147. Other arguments raised dealt with double taxation, Rosenbaum "Are Family Responsibility Laws Constitutional?" 1967 1(4) Family Law Quarterly 55 71; and Ross 200816 The Elder Law Journal 69, and privacy (Rosenbaum 1967 1(4) Family Law Quarterly 71).

$91 \mathrm{~S} 16$

92 The financial criteria are set out in regulations 18-20, as read with Annexure A. Reg 19 sets the parameters for the determination of means: The income is deemed to be either annual income, or half the annual income of the spouses (reg 19(1)). For definition of "income", see discussion below.

93 S 10 read with reg 2 (GN R898 of 2008 in GG 31356 of 22 Aug 2008). 
The financial criteria are based on a means test, and centre on the income $^{94}$ of the applicant and his/her spouse - irrespective of the matrimonial property regime. ${ }^{95}$ Several assets are considered: ${ }^{96}$ property owned (but not occupied), property held under leasehold, or any other property rights of the applicant or the spouse; investments, bonds, loans or outstanding debts in favour of the applicant; shares, share capital or interest in assets of a company; endowment policies after maturity date; and any lump-sum investment. If an applicant had impoverished himself or relinquished assets (by donation, transfer or sale under market value) in order to obtain a social grant, the value of such assets will also be taken into account. $^{97}$

Some deductions are permissible when calculating the income $^{98}$ including pension, provident or retirement annuity fund contributions, or other contributions not exceeding $22 \%$ of the net income, tax deductions, medical scheme membership fees, and contributions to the unemployment insurance fund.

The maximum amount of an older person's grant is determined by the Minister of Social Development with the concurrence of the Minister of Finance - by notification in the Government Gazette. From 1 April 2015 the grant was R1410 for older persons between 60 and 74 years, and R1430 for those who are 75 and older. ${ }^{99}$ The formula for the determination of the value of the older persons' grant is: $\mathrm{D}=1,6 \mathrm{~A}-0,4 \mathrm{~B} \cdot{ }^{100}$ No grant less than R100 per month is payable. ${ }^{101}$ Where the applicant is maintained in a State institution, the grant is reduced to $25 \%$ of the maximum amount of the grant. ${ }^{102}$

The procedure for application is prescribed in the Act, ${ }^{103}$ and the South African Social Security Agency (SASSA) - established in terms of the South African Social Security Agency Act 9 of 2004 - is responsible for the payment of the grants.

94 Income is defined in reg 19 (1) as "the annual income for an applicant, or half the annual income of the applicant and the spouse. "Income" includes any compensation payable to an applicant/spouse/dependent child; any profits, withdrawals or benefits derived from a business concern/farm; any trust payment or inheritance; any payment derived from property rights; any pension or annuity; any ex gratia amount; any rental for accommodation; any profits, withdrawals or benefits derived from farming activities; any maintenance; any other income, including interest and dividends; and any income or financial support derived from a South African or international organisation, excluding social assistance (reg 19)

95 Reg 18(2). Reg 18(3) makes provision for exceptions in the case of desertion and unwillingness to support.

96 Reg 19(3)-(4).

$97 \quad \operatorname{Reg} 19(5)$

98 Reg 20.

99 Regulation GN 277 of 2015 in GG 38647 of 30 March 2015.

$100 \mathrm{~A}=$ the maximum social grant payable per annum as approved; $\mathrm{B}=$ the annual income, and $\mathrm{D}=$ annual social grant amount payable, which must not exceed the amount equal to $A$ (Annexure $A(2))$.

101 Annexure $A(5)$. In addition, no grant is paid to a person not in a spousal relationship whose total assets exceed 55 times $A$ or to any person in a spousal relationship whose total assets exceeds 110 times [A] (Annexure $A(6))$.

102 Reg 22(1). This currently amounts to R352.50 and R357.50 respectively.

103 S 14 
Grants for the elderly should not be seen in isolation, as older persons are entitled to free primary healthcare services, and old-age grant beneficiaries are also eligible to receive free secondary healthcare services at public hospitals. ${ }^{104}$

From the discussion above, it is clear that there are many differences between the common-law and State duties to maintain the elderly: the source of the duty (common law versus statutory duty), the funding (private versus public funding), and the implementation thereof (agreement or court order versus a statutory obligation). The State grant is also a limited amount - but a common-law claim is dependent on the living standards of the parties. In addition, the State grant is only given prospectively, while a civil action can be brought in terms of the common law to retrospectively be refunded for maintenance sums already paid by a third party in supporting an indigent parent.

As far as the interaction of the two systems is concerned, no specific provisions are made. Heaton notes that it is "the state's duty to step in if the ... family fails or are unable to meet their obligations", ${ }^{105}$ indicating that the duty falls on the family first. However, where a parent qualifies for maintenance from a child, there is nothing prohibiting the same parent from also claiming the State grant, although the maintenance paid by the child will be taken into account. Similarly, where the indigent parent receives a State grant, this should be included in the calculation of the maintenance claim against the child.

\section{POLICY DEBATE: ARGUMENTS FOR FILIAL VERSUS STATE RESPONSIBILITY}

As mentioned above, a robust debate rages in America on whether ${ }^{106}$ filial or State responsibility for the support of the indigent elderly should prevail and these arguments are also germane to the South African situation.

104 Only a small percentage of the elderly have access to medical schemes (Stats SA Report 93). There are huge differences in medical aid access by population group. In 2012, more than $73,9 \%$ of elderly white people had access to a medical aid, compared to only $35 \%$ of elderly Indians/Asians, $15,9 \%$ of elderly coloured people, and 5,5\% of black Africans (Stats SA Report 106).

105 Heaton Family Law of South Africa 321.

106 Blair “'Honor thy Father and thy Mother' - But for How Long? - Adult Children's Duty to Care for and Protect Elderly Parents" 1996-1997 35 Journal of Family Law 765-782; Edelstone "Filial Responsibility: Can the Legal Duty to Support Our Parents Be Effectively Enforced?" 2002 36(3) Family Law Quarterly 501-514; Harkness "What are Families For? Re-evaluating Return to Filial Responsibility Laws" 201421 Elder LJ 305-344; Kline 1992 26(3) Family Law Quarterly 195-210; Kroll "To Care or Not to Care: The Ultimate Decision for Adult Caregivers in a Rapidly Aging Society" Spring 2012 Temple Political and Civil Rights LR 403-441; Levy and Gross "Constitutional Implications of Parental Support Laws" 1978-1979 13 University of Richmond LR 517-531; Liu "Filial Obligation: When Confucian meets the West" 200310 UCL Jurisprudence Review 43-67; Lopes "Filial Support and Family Solidarity" 19756 Pacific LR 508-535; Lundberg 200911 Journal of Law and Family Studies 533-539; Moskowitz "Filial Responsibility Statutes: Legal and Policy Considerations" 2000-2001 9 Journal of Law and Policy 709-736; Moskowitz "Adult Children and Indigent Parents: Intergenerational Responsibilities in International Perspective" 2002 86(3) Marquette LR 401-455; Narayanan "The Government's Role in Fostering the Relationship Between Adult Children and Their Elder Parents: From Filial 
The arguments that have been raised for assigning care of the elderly to able adult children are mostly within a socio-historical context: ${ }^{107}$ First there are family bonds, ${ }^{108}$ honour and gratitude as well as loyalty and altruism. ${ }^{109}$ Second, there is assumed promise or implied contract: ${ }^{10}$ indebtedness and reciprocity for the years that the parents had maintained them as children; ${ }^{111}$ however, the counter-argument is that this assumed promise or implied contract is over-broad, as parents make a conscious decision to have children and create the maintenance duty themselves - but children did not make the choice or promise or contract to provide these necessities. ${ }^{112}$ Third, the duty emanates from the friendship relationship that now exists between the parent and child. ${ }^{113}$ Fourth, the need of the parents creates a basis for the obligation - as there is a duty to protect vulnerable people that falls within a specific realm of status such as close family ties. ${ }^{114}$ Fifth, the duty is based on a romanticised notion of family caregiving, as the family is uniquely set to provide a warm and comfortable environment; ${ }^{115}$ however, the reality is that there are many dysfunctional families where the addition of an elderly parent will create additional tension as a result of the added

Responsibility Laws to ... What? A Cross-Cultural Perspective" 19964 Elder LJ 369-406; Pakula "A Federal Filial Responsibility Statute: A Uniform Tool to Help Combat the Wave of Indigent Elderly" 2005 39(3) Family Law Quarterly 859-877; Park "The Parent Trap: Health Care and Retirement Corporation of America v Pittas, How it Reinforced Filial Responsibility Laws and Whether Filial Responsibility Laws can Really Make You Pay" 20135 Estate Planning and Community Property LJ 441-463; Plaisance "Will you still ... when I'm sixtyfour: Adult Children's Legal Obligations to Aging Parents" 200821 Journal of the American Academy of Matrimonial Lawyers 245-270; Rosenbaum 1967 1(4) Family Law Quarterly 55-76; Ross 200816 The Elder Law Journal 167-171; Sketchley and McMillan "Filial Responsibility: Breaking the Backbone of Today's Modern Long Term Care System" Fall 2013 Saint Thomas LR 131-164; Silverstein and Yang "Intergenerational Support to Aging Parents. The Role of Norms and Needs" 2006 27(8) Journal of Family Issues 1068-1984; Stuifbergen and Van Delden "Filial Obligations to Elderly Parents: A Duty to Care?" 2011 Medicine, Health Care and Philosophy 63-71; Wainey "Preventing Family Feuds" April 2009 Trial 30; Walters 2000-2001 11 Journal of Contemporary Legal Issues 276-379; and Wise "Caring for our Parents in an Aging World: Sharing Public and Private Responsibility for the Elderly" 20025 Legislation and Public Policy 563-589.

107 Wise 20025 Legislation and Public Policy 567-568. Liu discusses the various historical developments of Western theories of filial obligations towards parents, starting with Aristotle's demand for justice and friendship, utilitarianism and the maximising of parental happiness, Rawls's theory of justice, Blustein's gratitude theory, and English's friendship model (Liu 200310 UCL Jurisprudence Review 47-56).

108 Edelstone 2002 36(3) Family Law Quarterly 504.

109 In Roman and Roman Dutch law, it is referred to as an obligation ex jure sanguine (Lawrie "Reciprocal Duty of Support between Parent and Child in South African Law" 1938 SALJ 286-291).

110 Stuifbergen 2011 Medicine, Health Care and Philosophy 1; Levy and Gross 1978-1979 13 University of Richmond LR 528; Moskowitz 2000-2001 9 Journal of Law and Policy 721; and Pakula 2005 39(3) Family Law Quarterly 868.

111 Wise 20025 Legislation and Public Policy 568-569; Pakula 2005 39(3) Family Law Quarterly 864; Stuifbergen 2011 Medicine, Health Care and Philosophy 1; Levy and Gross 1978-1979 13 University of Richmond LR 523; and Ross 200816 The Elder Law Journal 185.

112 Wise 20025 Legislation and Public Policy 568; and Moskowitz 2000-2001 9 Journal of Law and Policy 723.

113 Stuifbergen 2011 Medicine, Health Care and Philosophy 1.

114 Ibid.

115 Wise 20025 Legislation and Public Policy 568; and Ross 200816 The Elder Law Journal 188. 
financial and emotional burden that may build resentment and stress, as well as shame and manipulation. ${ }^{116}$ Sixth, the argument is raised that public costs should be contained and that the tax burden and Government expenses should be decreased, ${ }^{117}$ as the State may not be able to provide the necessary care for all the needy elderly. ${ }^{11}$

On the other hand, the following arguments have been raised against the duty to be placed on the children and/or the family - but rather on the state: ${ }^{119}$ First, family loyalties and family ties are less close and binding today than a few generations ago, and children are less likely to support their parents voluntarily; the counter-argument is that although this may sometimes be the case, there is ample evidence that a large number of children are still voluntarily supporting their parents. ${ }^{120}$ Second, placing the responsibility on children pits family members against each other: parents against children and siblings against each other, ${ }^{121}$ and this often strains the relationships. ${ }^{122}$ Third, parents often are reluctant to claim support from their children for a variety of reasons, including guilt and shame; and if reliance is placed solely on private support, many elderly will remain destitute. ${ }^{123}$ Fourth, the legal principle creates a class-based care ${ }^{124}$ as the care will be dependent on the lifestyle of the family; it may be relatively costly for the family to support the elderly parent, and they may not have the necessary funds and may themselves also already be elderly; ${ }^{125}$ and linked hereto is the argument that such a claim prolongs poverty by forcing the younger generation to use resources to fund the elderly. ${ }^{126}$ Fifth, placing the burden on the family has gender implications, as it inevitably would exacerbate gender inequality - as the additional load will generally be borne by woman. ${ }^{127}$ Sixth, expecting the family to carry the burden involves the law in the private sphere, where the law should not be involved. Seventh, the principles are not applicable to all destitute elderly, as some may never have had children, or their children may have predeceased them. Eighth, Kline also argues that children should not be responsible for the support of their

116 Wise 20025 Legislation and Public Policy 571-572.

117 Kline 1992 26(3) Family Law Quarterly 204; Moskowitz 2000-2001 9 Journal of Law and Policy 721; Pakula 2005 39(3) Family Law Quarterly 868; Edelstone 2002 36(3) Family Law Quarterly 504; and Ross 200816 The Elder Law Journal 185.

118 Wise 20025 Legislation and Public Policy 569-570.

119 Wise 20025 Legislation and Public Policy 563-578.

120 Moskowitz 2000-2001 9 Journal of Law and Policy 721.

121 Britton 1989-1990 26 California Western LR 368.

122 Lopes 19756 Pacific LR 524; Edelstone 2002 36(3) Family Law Quarterly 506; and Sketchley and McMillan Fall 2013 Saint Thomas LR 154

123 Levy and Gross 1978-1979 13 University of Richmond LR 531.

124 In South Africa, because of the poverty statistics, the issue may also reinforce racial imbalances.

125 Britton 1989-1990 26 California Western LR 369.

126 Britton 1989-1990 26 California Western LR 368-388; Lopes 19756 Pacific LR 526-527; and Ross 200816 The Elder Law Journal 191.

127 See also Pakula 2005 39(3) Family Law Quarterly 859; Moskowitz 2000-2001 9 Journal of Law and Policy 724; Edelstone 2002 36(3) Family Law Quarterly 511; and Silverstein and Yang 2006 27(8) Journal of Family Issues 1071 and 1081. 
elderly parents for public policy reasons, ${ }^{128}$ and that there is a moral duty on society to care for the elderly. ${ }^{129}$

\section{RECOMMENDATIONS}

Wise argues for a shared responsibility, and striking a balance, in that both the State and the siblings should share the responsibility of supporting the indigent elderly. ${ }^{130}$ The State should, he argues, empower children to support their parents through a variety of programmes and strategies: tax deductions, ${ }^{131}$ leave benefits ${ }^{132}$ and workplace support combined with public services. ${ }^{133}$ In addition, loans for incorporating fixtures to accommodate homecare for the elderly ${ }^{134}$ should be considered - as well as other caregiver payment programmes. ${ }^{135}$

It is submitted that all these options are also viable options within the South African context, and the State is already moving in this direction with the Tax Laws Amendment Act. From a policy perspective in South Africa, the State cannot afford to support all indigent parents, as this would create an unfair financial burden on the State. Financially able children should, however, be required to assist with the support of their indigent parents.

There are several solutions that can be suggested in the civil sphere to ensure that the elderly are properly cared for at retirement: Education, financial planning and insurance during the lifetime would ensure private resources when they are required and will ease the burden - but in a country like South Africa where poverty is rife, this is not an option for all citizens. The legislature may consider amending the labour laws, extending family medical leave to ensure families have the time to care for their elderly without fear of unemployment. With expansion of other State social-welfare assistance like university fees and a national health system - citizens could be enabled to make provision for their old age. Another option may be a personal service contract between parent and child may, where the duties, rights and responsibilities - both financial and otherwise - are set out upfront. ${ }^{136}$ Whether a parent-child contract would be a solution is, however, doubtful. ${ }^{137}$

128 Kline 1992 26(3) Family Law Quarterly 207.

129 Kline 1992 26(3) Family Law Quarterly 205. See, also, Wise 20025 Legislation and Public Policy 577.

130 Wise 20025 Legislation and Public Policy 565.

131 Wise 20025 Legislation and Public Policy 583; Moskowitz 2000-2001 9 Journal of Law and Policy 723; and Narayanam 1996 Elder Law Journal 396.

132 See, also, Moskowitz 2000-2001 9 Journal of Law and Policy 729; and Narayanam 19964 Elder Law Journal 399-400.

133 Wise 20025 Legislation and Public Policy 583; and Narayanam 19964 Elder Law Journal 370.

134 Narayanam 19964 Elder Law Journal 392-393.

135 Wise 20025 Legislation and Public Policy 591. South Africa already has grant-in-aid assistance - although limited in scope.

136 Wainey April 2009 Trial 30; and Kroll Spring 2012 Temple Political and Civil Rights LR 415416.

137 See argument by Bonthuys "Family Contracts" 2004 121(4) SALJ 879 899-900 - on family contracts. 


\section{$7 \quad$ CONCLUSION}

From the above discussion, it is obvious that the number of indigent elderly continues to rise. This is partly due to the continued premature deaths of the younger, economically active generation. For the elderly, the consequences are twofold: the untimely termination of a financial source of support, and the responsibility to head and run various generational households. In the circumstances, the State grant becomes the only dependable financial source of income for the elderly. Consequently, the State will have to continue to support the growing group of indigent elderly. South Africa cannot, however, afford moving towards an exclusive burden on the State: the fiscus will always be limited. It is submitted that families that can afford it have a role to play - both legally and ethically - to assist the indigent elderly.

It is submitted that there should thus not be a change in either the policy nor the law, as both remain applicable in South Africa. Society should look outside the legal fraternity to strengthen the solutions to the problem of indigence in old age. Although the State has commenced the planning towards promoting self-sufficiency for old-age through the mooted tax legislation, this is not sufficient in itself - and more is needed.

Education to inform indigent parents of the duty of financially able children, as well as providing a mediated approach to maintenance claims would go a long way in ensuring that the burden on the State is as light as possible - and that financially able children are held accountable. These possibilities would be a good place for the debate to start - in the search of sustainable solutions. 


\section{$7 \quad$ CONCLUSION}

From the above discussion, it is obvious that the number of indigent elderly continues to rise. This is partly due to the continued premature deaths of the younger, economically active generation. For the elderly, the consequences are twofold: the untimely termination of a financial source of support, and the responsibility to head and run various generational households. In the circumstances, the State grant becomes the only dependable financial source of income for the elderly. Consequently, the State will have to continue to support the growing group of indigent elderly. South Africa cannot, however, afford moving towards an exclusive burden on the State: the fiscus will always be limited. It is submitted that families that can afford it have a role to play - both legally and ethically - to assist the indigent elderly.

It is submitted that there should thus not be a change in either the policy nor the law, as both remain applicable in South Africa. Society should look outside the legal fraternity to strengthen the solutions to the problem of indigence in old age. Although the State has commenced the planning towards promoting self-sufficiency for old-age through the mooted tax legislation, this is not sufficient in itself - and more is needed.

Education to inform indigent parents of the duty of financially able children, as well as providing a mediated approach to maintenance claims would go a long way in ensuring that the burden on the State is as light as possible - and that financially able children are held accountable. These possibilities would be a good place for the debate to start - in the search of sustainable solutions. 